\title{
Profiles of Staphyloccocus aureus isolated from goat persistent mastitis before and after treatment with enrofloxacin
}

\author{
Magna Coroa Lima', Mariana de Barros ${ }^{1}$, Thalita Moreira Scatamburlo', Richard Costa Polveiro', \\ Laís Karolyne de Castro ${ }^{1}$, Samuel Henrique Sales Guimarães ${ }^{1}$, Sanely Lourenço da Costa ${ }^{1}$, \\ Mateus Matiuzzi da Costa ${ }^{2}$ and Maria Aparecida Scatamburlo Moreira ${ }^{1 *}$ (D)
}

\begin{abstract}
Background: Staphylococcus aureus is one of the main causative agents of mastitis in small ruminants. Antimicrobial use is the major treatment, but there are many flaws linked to resistance, tolerance or persistence. This study aimed to verify changes in resistance, virulence and clonal profiles of $S$. aureus isolated from persistent mastitis goat milk before and after enrofloxacin treatment.

Results: MIC increased to at least one antimicrobial in S. aureus isolates after enrofloxacin treatment compared to before. The most detected resistance genes before and after treatment were tetK, tet $M$, and blaZ, with more resistance genes detected after enrofloxacin treatment $(p<0.05)$. Occasional variations in efflux system gene detection were observed before and after treatment. Nine virulence genes ( $h l a, f n b A$, fnbB, eta, etb, sea, sec, seh, and sej) were detected at both times, and between these, the hla and eta genes were detected more in isolates after treatment. All isolates of S. aureus belonged to the same sequence type (ST) 133, except for two S. aureus isolates prior to enrofloxacin treatment which were classified as ST5 and the other as a new one, ST4966. Isolates of S. aureus 4, 8, and 100 from before and after treatment had identical pulse types, while others obtained from other animals before and after treatment were classified into distinct pulse types.

Conclusion: There were occasional changes in the studied profiles of $S$. aureus isolated before and after treatment of animals with enrofloxacin, which may have contributed to the permanence of bacteria in the mammary gland, even when using traditional treatment, resulting in persistent mastitis.
\end{abstract}

Keywords: Caprine mastitis, Small ruminants, Persistence

\section{Background}

Goat farms suffer severe economic losses due to staphylococcal intramammary infections, with Staphylococcus aureus being the main cause of clinical mastitis in small ruminants [1]. Intramammary infections caused by S. aureus deserve special attention, due to the high

\footnotetext{
* Correspondence: masm@ufv.br

${ }^{1}$ Laboratory of Bacterial Diseases (LDBAC), Veterinary Department,

Universidade Federal de Vicosa (UFV), PH Rolfs Avenue, s/n, University Campus, Viçosa, Minas Gerais 36570-900, Brazil

Full list of author information is available at the end of the article
}

prevalence and diverse forms of presentation of the disease. S. aureus is responsible for both acute clinical mastitis (gangrenous mastitis) and subclinical mastitis [2].

Mastitis is traditionally treated with the use of antimicrobials; however, the success of this therapy is low in many cases. The use of enrofloxacin in goats and other small ruminants in mastitis treatments has been widely accepted by the main routes of administration and has proved its efficacy in the resolution of mastitis [3, 4]. The phenomena of resistance, tolerance and persistence

C C The Author(s). 2020 Open Access This article is licensed under a Creative Commons Attribution 4.0 International License, which permits use, sharing, adaptation, distribution and reproduction in any medium or format, as long as you give appropriate credit to the original author(s) and the source, provide a link to the Creative Commons licence, and indicate if changes were made. The images or other third party material in this article are included in the article's Creative Commons licence, unless indicated otherwise in a credit line to the material. If material is not included in the article's Creative Commons licence and your intended use is not permitted by statutory regulation or exceeds the permitted use, you will need to obtain permission directly from the copyright holder. To view a copy of this licence, visit http://creativecommons.org/licenses/by/4.0/ The Creative Commons Public Domain Dedication waiver (http://creativecommons.org/publicdomain/zero/1.0/) applies to the data made available in this article, unless otherwise stated in a credit line to the data. 
have brought greater complexity to the flaws of antimicrobial therapies [5]. S. aureus possesses different virulence factors that contribute to its persistence in mammary tissue [6]. Besides, the pattern of virulence genes can be used to determine the biovar and the relationship with the origin of the isolates [7]. In addition to virulence, a major concern in the control of mastitis is resistance to antimicrobials of the etiological agent. Finally, the characterization of the genetic diversity of $S$. aureus is important to understand the pattern of dispersion of the pathogen [6].

In this way, the present study aims to verify changes in the clonal, resistance and virulence profiles of S. aureus isolated from the milk of goats with persistent mastitis, before and after treatment with enrofloxacin.

\section{Results}

\section{Resistance profile}

The minimum inhibitory concentration (MIC) values are shown in Table 1. Considering the same animal, a MIC increase to at least one antimicrobial was observed for all $S$. aureus isolates after treatment, compared with the values found before it. This was observed in a greater number of isolates for enrofloxacin, ciprofloxacin, and oxacillin MIC values, followed by penicillin, gentamicin, and ampicillin, then by vancomycin and lastly by tetracycline MICs (Table 1, in bold).

According to the cutoff points of the Clinical and Laboratory Standards Institute [8] and Macgowan and Wise [9], all isolates showed resistance profiles for tetracycline, penicillin, ampicillin and oxacycline, while for the other antimicrobials there were variations (Table 1). In addition, after treatment some $S$. aureus isolates changed the profile for antimicrobial resistant to vancomycin and ciprofloxacin, as highlighted in Table 1.

The most frequently detected resistance genes in $S$ aureus isolates before and after treatment were tet $K$, tet $M$ and blaZ (Table 2). More resistance genes were detected in the isolates obtained after treatment with enrofloxacin $(60.87 \%, 28 / 46)$ compared to those detected in $S$. aureus isolated prior to treatment $(39.13 \%, 18 / 46)$ $(P<0.05)$. The genes aac (6')/aph (2'), aph(3')-llla and erm $C$ were not detected at both moments.

S. aureus from animals 7 and 9 showed greater variation in the amount of resistance genes detected before and after treatment (Table 2).

Regarding multidrug efflux systems genes, norC and tet38 were the most prevalent, being found in 17 of 18 isolates (94.4\%) (Table 2). S. aureus from animal 9 varied the most: there was no gene before treatment and after

Table 1 Values of Minimum Inhibitory Concentration of different antimicrobials in Staphylococcus aureus isolates using the E-test ${ }^{\circledR}$

\begin{tabular}{|c|c|c|c|c|c|c|c|c|}
\hline Isolates & $\begin{array}{l}\text { GEN } \\
(R \geq 16)\end{array}$ & $\begin{array}{l}\text { TET } \\
(R \geq 16)\end{array}$ & $\begin{array}{l}\text { VAN } \\
(R \geq 16)\end{array}$ & $\begin{array}{l}\text { ENR } \\
(R \geq 8)\end{array}$ & $\begin{array}{l}\text { CIP } \\
(R \geq 4)\end{array}$ & $\begin{array}{l}\text { OXA } \\
(R \geq 4)\end{array}$ & $\begin{array}{l}\text { PEN } \\
(R \geq 0,25)\end{array}$ & $\begin{array}{l}\text { AMP } \\
\left(R \geq 2^{*}\right)\end{array}$ \\
\hline$\overline{4^{c}}$ & 3 & $\underline{125}$ & 0,25 & 0,19 & 3 & 24 & $\underline{24}$ & $\underline{3}$ \\
\hline $4^{p}$ & 6 & $\underline{32}$ & 0,145 & 0,75 & 3 & $\underline{24}$ & $\underline{24}$ & $\underline{16}$ \\
\hline $5^{c}$ & 12 & 64 & 3 & 0,38 & 3 & 24 & $\underline{16}$ & 12 \\
\hline $5^{p}$ & 12 & $\underline{16}$ & 3 & 1,25 & $\underline{12}^{1}$ & $\underline{32}$ & $\underline{16}$ & $\underline{12}$ \\
\hline $6^{c}$ & 3 & $\underline{16}$ & 1,5 & 0,38 & $\underline{96}$ & $\underline{32}$ & $\underline{8}$ & $\underline{16}$ \\
\hline $6^{p}$ & 6 & $\underline{24}$ & $\underline{16}^{1}$ & 0,75 & $\underline{96}$ & $\underline{42}$ & $\underline{96}$ & $\underline{24}$ \\
\hline $7^{c}$ & 4 & $\underline{36}$ & $\underline{18}$ & 0,125 & 0,25 & 24 & 24 & 12 \\
\hline $7^{p}$ & 8 & 32 & $\underline{18}$ & 0,19 & 0,48 & 24 & 24 & 12 \\
\hline $8^{c}$ & 3 & $\underline{96}$ & 6 & 0,25 & 0,64 & $\underline{12}$ & $\underline{12}$ & $\underline{2}$ \\
\hline $8^{p}$ & 4 & $\underline{96}$ & 12 & 0,25 & 3 & 32 & 32 & $\underline{2}$ \\
\hline $9^{c}$ & 1 & $\underline{96}$ & $\underline{32}$ & 0,19 & 3 & $\underline{32}$ & $\underline{32}$ & $\underline{4}$ \\
\hline $9^{p}$ & 0,5 & $\underline{96}$ & 32 & 0,5 & 3 & $\underline{48}$ & 38 & $\underline{4}$ \\
\hline $10^{c}$ & 12 & $\underline{48}$ & $\underline{48}$ & 0,75 & 3 & $\underline{48}$ & $\underline{48}$ & $\underline{48}$ \\
\hline $10^{p}$ & 3 & $\underline{48}$ & $\underline{48}$ & 0,75 & $\underline{4}^{1}$ & $\underline{96}$ & $\underline{96}$ & $\underline{48}$ \\
\hline $100^{c}$ & 4 & $\underline{48}$ & $\underline{48}$ & 0,5 & 2 & 12 & $\underline{12}$ & $\underline{12}$ \\
\hline $100^{p}$ & 2 & $\underline{48}$ & $\underline{96}$ & 0,5 & $\underline{12}^{1}$ & $\underline{12}$ & $\underline{12}$ & $\underline{16}$ \\
\hline $101^{c}$ & $\underline{48}$ & $\underline{18}$ & 3 & $\underline{16}$ & $\underline{6}$ & $\underline{96}$ & $\underline{0,75}$ & $\underline{16}$ \\
\hline $101^{p}$ & $\underline{48}$ & $\underline{18}$ & 3 & $\underline{16}$ & $\underline{6}$ & $\underline{96}$ & $\underline{0,75}$ & $\underline{18}$ \\
\hline
\end{tabular}

Values of MIC in micrograms per milliliter $(\mu \mathrm{g} / \mathrm{mL})$ of different antimicrobials in Staphylococcus aureus isolated from goats with mastitis before (c) and after $(p)$ enrofloxacin treatment using the E-test ${ }^{\oplus}$ (bioMerieux). $R$ resistance. GEN Gentamicin; TET Tetracycline; VAN Vancomycin; ENR Enrofloxacin; CIP Ciprofloxacin; OXA Oxacillin; PEN Penicillin, AMP Ampicillin. Underlined number: resistant for the antimicrobial in test. Bold number: MIC value increased in the isolates obtained in the same animal prior and after enrofloxacin treatment. 'Sensitivity profile change for resistance in the isolates obtained in the same animal prior and after enrofloxacin treatment. Breakpoint: CLSI [8]. *Breakpoint MacGowan and Wise [9] 
Table 2 Virulence and resistance genes detected in Staphylococcus aureus isolates from mastitis goat milk

\begin{tabular}{|c|c|c|}
\hline Isolates & Resistance profile & Virulence profile \\
\hline$\overline{4^{c}}$ & blaZ, ermA, mecA, tetK, tetM, ImrS, norA, norC, tet38 & $f \cap b A, f n b B, h l a$ \\
\hline $4^{p}$ & blaZ, ermA, mecA, tetK, tetM, ImrS, norA, norC, tet38 & $f n b A, f n b B$, hla, eta \\
\hline $5^{c}$ & erma, tetK, tetM, norA, norC, tet38 & eta, fnbB, sea, sej \\
\hline $5^{p}$ & ant $\left(4^{\prime}\right)-l a$, tetK, tetM., ImrS, norA, norC, tet38 & eta, fnbB, hla, sea, sej, \\
\hline $6^{c}$ & ant $\left(4^{\prime}\right)-l a$, blaZ, tetM, tetK, norA, norC, tet38 & etb, sec, sej \\
\hline $6^{p}$ & $\operatorname{ant}\left(4^{\prime}\right)-l a$, blaZ, tetM, tetK, norA, norC, tet38 & etb, sec, sej \\
\hline $7^{c}$ & blaZ, norA, norC, tet38 & $f n b A, f n b B$, hla \\
\hline $7^{p}$ & ant $\left(4^{\prime}\right)-l a$, blaZ, ermB, tetM, tetK, ImrS, norA, norC, tet38 & $f n b A, f n b B$, hla \\
\hline $8^{c}$ & ermB, ImrS, norC, tet38 & etb, hla \\
\hline $8^{p}$ & ermB, ImrS, norC, tet38 & etb, hla \\
\hline $9^{c}$ & blaZ, mecA & etb, sea, \\
\hline $9^{p}$ & blaZ, mecA, tetM, tetK, norA, norC, tet38 & $e t b$, hla, sea \\
\hline $10^{c}$ & ant $\left(4^{\prime}\right)-$ la norC, tet38 & hla, seh \\
\hline $10^{p}$ & $\operatorname{ant}\left(4^{\prime}\right)-1 a$, norC, tet38 & hla, seh \\
\hline $100^{c}$ & tetK, tetM, norC, tet38 & fnbA, hla, sec \\
\hline $100^{p}$ & tetK, tetM, norC, tet38 & $e t b, f n b A, h l a, s e c$ \\
\hline $101^{c}$ & ant $\left(4^{\prime}\right)-l a$, blaZ, tetM, tetK, norA, norC, tet38 & $e t b, f n b B, h l a, s e c$ \\
\hline $101^{p}$ & ant $\left(4^{\prime}\right)-l a$, blaZ, tetM, tetK, norA, norC, tet38 & etb, fnbB, hla, sec \\
\hline
\end{tabular}

c: isolates of goats with mastitis before treatment; $\mathrm{p}$ : isolates of goats with mastitis after treatment. Bold: multidrug efflux system genes

treatment it was positive for three genes. Moreover, in isolates from animals 5 and 7, after treatment the $\operatorname{lmrS}$ gene was detected in addition to the genes that were detected also before treatment. The norB, $m g r A$ and $m s r A$ genes were not detected in $S$. aureus isolated at the two studied moments.

\section{Virulence profile}

The detection of S. aureus virulence genes isolated from goat milk with clinical mastitis before and after treatment with enrofloxacin are shown in Table 2 . Of the 16 genes tested, only nine genes (hla, fnbA, fnbB, eta, etb, $s e a, s e c$, seh and $s e j$ ) were detected in S. aureus isolated before and after enrofloxacin treatment. Among these, the genes hla (alpha-hemolysin) and eta (exfoliative toxin A) were more detected in S. aureus isolated after treatment. However, there were no statistical difference. The others, related to adhesion and toxins, remained constant at both times.

\section{Clonal profile}

S. aureus isolates from the animals 4,8 and 100 , before and after treatment, presented identical pulse types, whereas others obtained from other animals, before and after treatment, were classified into distinct or even unclassified pulse types using $95 \%$ similarity and 5\% tolerance and optimization, as shown in Fig. 1.

From the MLST, all S. aureus isolates belonged to the same ST 133, except $S$. aureus 5 and 101 isolated before treatment with enrofloxacin. Isolate $5^{\mathrm{c}}$ belonged to ST 5 and S. aureus $101^{\mathrm{c}}$ was classified as a novel ST 4966 (Fig. 1).

\section{Discussion}

In goats mastitis, the most important bacterial genus is Staphylococcus $[10,11]$ and the severity of the infections caused by $S$. aureus in different types of mastitis is associated with its virulence factors which allow it to adhere to surface, invade or avoid the immune system, and cause harmful toxic effects to the host $[12,13]$.

In general, considering the same animal as origin, the MICs of the tested antimicrobials increased for the isolates obtained after treatment and in some cases changed the profile for resistance (Table 1). There was an increase in the MIC for enrofloxacin in five isolates obtained after treatment, whereas in four isolates, the MIC was maintained (Table 2). The mechanism of action of fluoroquinolones is to inhibit DNA gyrase and thus inhibit bacterial cell division. For beta-lactams and fluoroquinolones, the inhibition of replication plays a central role in the development of the persistence phenomenon [5]. Persisters are not as dormant as spores but are slow or very slow growers [14]. In addition, gene exchange events can be increased up to 100 -fold in persistent $S$. aureus isolates [15].

Of the 10 resistance genes tested, seven were detected in $S$. aureus isolated before and after treatment, but with a greater detection in isolates after treatment $(p<0.05)$. 
Table 3 Primers used in the detection of Staphylococcus aureus resistance, multidrug efflux system and virulence genes

\begin{tabular}{|c|c|c|c|c|c|}
\hline Category & Gene & Primer & Sequence & Product (bp) & Reference \\
\hline \multirow[t]{20}{*}{ Resistance } & \multirow[t]{2}{*}{ mecA } & mecA - $f$ & CCTAGTAAAGCTCCGGAA & \multirow[t]{2}{*}{314} & \multirow[t]{2}{*}[59]{} \\
\hline & & mecA - $r$ & CTAGTCCATTCGGTCCA & & \\
\hline & \multirow[t]{2}{*}{$\operatorname{Aac}\left(6^{\prime}\right) / a p h\left(2^{\prime}\right)$} & $\operatorname{Aac}\left(6^{\prime}\right) / a p h\left(2^{\prime}\right)-f$ & GAAGTACGCAGAAGAGA & \multirow[t]{2}{*}{491} & \multirow[t]{2}{*}{ [59] } \\
\hline & & $\operatorname{Aac}\left(6^{\prime}\right) / a p h\left(2^{\prime}\right)-r$ & ACATGGCAAGCTCTAGGA & & \\
\hline & \multirow[t]{2}{*}{$a p h\left(3^{\prime}\right)-111 a$} & $a p h\left(3^{\prime}\right)-111 a-f$ & AAATACCGCTGCGTA & \multirow[t]{2}{*}{242} & \multirow[t]{2}{*}{ [59] } \\
\hline & & $a p h\left(3^{\prime}\right)-111 a-r$ & CATACTCTTCCGAGCAA' & & \\
\hline & \multirow[t]{2}{*}{ ant $\left(4^{\prime}\right)-1 a$} & $\operatorname{ant}\left(4^{\prime}\right)-1 a-f$ & AATCGGTAGAAGCCCAA & \multirow[t]{2}{*}{135} & \multirow[t]{2}{*}[59]{} \\
\hline & & $a n t\left(4^{\prime}\right)-1 a-r$ & GCACCTGCCATTGCTA & & \\
\hline & \multirow[t]{2}{*}{ tet(M) } & $\operatorname{tet}(M)-f$ & AGTGGAGCGATTACAGAA & \multirow[t]{2}{*}{360} & \multirow[t]{2}{*}[60]{} \\
\hline & & $\operatorname{tet}(M)-r$ & CATATGTCCTGGCGTGCTTA & & \\
\hline & \multirow[t]{2}{*}{$\operatorname{tet}(K)$} & $\operatorname{tet}(K)-f$ & GTAGCGACAATAGGTAATAGT & \multirow[t]{2}{*}{158} & \multirow[t]{2}{*}[60]{} \\
\hline & & $\operatorname{tet}(K)-r$ & GTAGTGACAATAAACCTCCTA & & \\
\hline & \multirow[t]{2}{*}{ blaz } & blaz - $f$ & ACTTCAACACCTGCTGCTTC & \multirow[t]{2}{*}{173} & \multirow[t]{2}{*}[60]{} \\
\hline & & blaz - r & TGACCACTITTATCAGCAACC & & \\
\hline & \multirow[t]{2}{*}{ ermA } & $e r m A-f$ & TATCTTATCGTTGAGAAGGGATT & \multirow[t]{2}{*}{139} & [61] \\
\hline & & ermA - r & CTACACTTGGCTTAGGATGAAA & & \\
\hline & ermB & $e r m B-f$ & СTATCTGATTGTTGAAGAAGGATT & 142 & [61] \\
\hline & & $e r m B-r$ & GTTAACTCTTGGTTTAGGATGAAA & & \\
\hline & ermC & erm $C-f$ & CTTGTTGATCACGATAATTTCC & 299 & {$[61]$} \\
\hline & & ermC - r & ATCTIITAGCAAACCCGTATTC & & \\
\hline Multidrug Efflux Pump & tet38 & tet38 - $f$ & TTCAGTTTGGTTATAGACAA & 400 & [61] \\
\hline & & tet38 - r & CGTAGAAATAAATCCACCTG & & \\
\hline & norA & norA - $f$ & TGCAATTTCATATGATCAATCCC & 150 & [29] \\
\hline & & norA - $r$ & AGATTGCAATTCATGCTAAATAT & & \\
\hline & norB & norB $-f$ & ATAAGGTAAGATAACTAGCA & 150 & [29] \\
\hline & & $n o r B-r$ & ATCTCTATTTGCCTCCCTATA & & \\
\hline & norC & norc - $f$ & AAATGGTTCTAAGCGACCAA & 200 & [29] \\
\hline & & norc $-r$ & ATAAATACCTGAAGCAACGC & & \\
\hline & LmrS & LmrS - $f$ & TAAAGTTGAATTAACAAC & 180 & {$[30]$} \\
\hline & & LmrS-r & GCGGATCCTTAAAATTTC & & \\
\hline & mgrA & $m g r A-f$ & CGAATTCATTCATGATTT & 200 & [61] \\
\hline & & $m g r A-r$ & AAAGTTGATTGTTTATTAA & & \\
\hline & $m s r A$ & $m s r A-f$ & TCCAATCATAGCACAAAATC & 163 & {$[61]$} \\
\hline & & $m s r A-r$ & AATTCCCTCTATTTGGTGGT & & \\
\hline Virulence & hla & hla $-f$ & CTGATTACTATCCAAGAAATTCGATTG & 209 & {$[62]$} \\
\hline & & hla $-r$ & CTTCCAGCCTACTTTTTATCAGT & & \\
\hline & $f n b A$ & $f n b A-f$ & GTGAAGTITAGAAGGTGGAAAGAITAG & 643 & [63] \\
\hline & & $f n b A-r$ & GCTCTTGTAAGACCATITTCTTCAC & & \\
\hline & $f \cap b B$ & $f n b B-f$ & GTAACAGCTAATGGTCGAATTGATACT & 524 & [63] \\
\hline & & $f n b B-r$ & CAAGTTCGATAGGAGTACTATGTTC & & \\
\hline & eta & eta $-f$ & ACTGTAGGAGCTAGTGCATTTGT & 190 & [64] \\
\hline & & eta $-r$ & TGGATACTIITGTCTATCTIITCATCAAC & & \\
\hline & etb & $e t b-f$ & CAGATAAAGAGCTTTATACACACATTAC & 621 & [64] \\
\hline & & $e t b-r$ & AGTGAACTTATCTTTCTATTGAAAAACACTC & & \\
\hline
\end{tabular}


Table 3 Primers used in the detection of Staphylococcus aureus resistance, multidrug efflux system and virulence genes (Continued)

\begin{tabular}{|c|c|c|c|c|c|}
\hline Category & Gene & Primer & Sequence & Product (bp) & Reference \\
\hline & \multirow[t]{2}{*}{ lukDE } & lukDE - $f$ & TGAAAAAGGTTCAAAGTTGATACGAG & \multirow[t]{2}{*}{269} & \multirow[t]{2}{*}{ [64] } \\
\hline & & lukDE - r & TGTATTCGATAGCAAAAGCAGTGCA & & \\
\hline & \multirow[t]{2}{*}{ tst } & tst- $f$ & TTCACTATTTGTAAAAGTGTCAGACCCACT & \multirow[t]{2}{*}{180} & \multirow[t]{2}{*}{ [64] } \\
\hline & & tst $-r$ & TACTAATGAATTTITTTATCGTAAGCCCTT & & \\
\hline & \multirow[t]{2}{*}{ sea } & sea $-f$ & ACGATCAATITTIACAG & \multirow[t]{2}{*}{544} & \multirow[t]{2}{*}{ [65] } \\
\hline & & sea $-r$ & TGCATGTITTCAGAGTTAATC & & \\
\hline & \multirow[t]{2}{*}{ seb } & $s e b-f$ & GAATGATATTAATTCGCATC & \multirow[t]{2}{*}{416} & \multirow[t]{2}{*}{ [65] } \\
\hline & & seb $-r$ & TCTITGTCGTAAGATAAACTTC & & \\
\hline & \multirow[t]{2}{*}{$\sec$} & $\sec -f$ & GACATAAAAGCTAGGAATTT & \multirow[t]{2}{*}{257} & \multirow[t]{2}{*}{ [65] } \\
\hline & & $\sec -r$ & AAATCGGATTAACATTATCCA & & \\
\hline & \multirow[t]{2}{*}{ sed } & sed - $f$ & CTAGTTTGGTAATATCTCCT & \multirow[t]{2}{*}{317} & \multirow[t]{2}{*}{ [65] } \\
\hline & & sed $-r$ & TAATGCTATATCTTATAGGG & & \\
\hline & \multirow[t]{2}{*}{ see } & see $-f$ & TAGATAAAGTTAAAACAAG & \multirow[t]{2}{*}{170} & \multirow[t]{2}{*}{ [65] } \\
\hline & & see $-r$ & TAACTTACCGTGGACCCTTC & & \\
\hline & \multirow[t]{2}{*}{ seg } & $\operatorname{seg}-f$ & GTTAGAGGAGGTTTATG & \multirow[t]{2}{*}{198} & \multirow[t]{2}{*}{ [65] } \\
\hline & & $\operatorname{seg}-r$ & TTCCTTCAACAGGTGGAGA & & \\
\hline & \multirow[t]{2}{*}{ seh } & seh $-f$ & CAACTGCTGATTTAGCTCAG & \multirow[t]{2}{*}{173} & \multirow[t]{2}{*}{ [65] } \\
\hline & & seh $-r$ & CCCAAACATTAGCACCA & & \\
\hline & \multirow[t]{2}{*}{ sei } & sei-f & GGCCACTITATCAGGACA & \multirow[t]{2}{*}{328} & \multirow[t]{2}{*}{ [65] } \\
\hline & & sei - r & AACTTACAGGCAGTCCA & & \\
\hline & \multirow[t]{2}{*}{ sej } & sej- $f$ & GTTCTGGTGGTAAACCA & \multirow[t]{2}{*}{131} & \multirow[t]{2}{*}{ [65] } \\
\hline & & sej - r & GCGGAACAACAGTTCTGA & & \\
\hline
\end{tabular}

The tet $M$ and tet $K$ genes are associated with tetracycline resistance. The gene tet $M$ is located in conjugative transposons, whereas the tet $K$ gene is located in a plasmid, which is the transfer of genes to other species of bacteria $[16,17]$. The blaZ gene encoding penicillin resistance may be located both chromosomally and in plasmids [17].

In the present study, the mecA gene was detected before and after treatment. Expression of this gene confers resistance to methicillin and most beta-lactams. The gene $m e c A$ is located on a mobile genetic element 'staphylococcal cassette chromosome mec (SCCmec) [18]. Methicillin-resistant S. aureus (MRSA) is an important human and animal pathogen that is linked to several infections. Recently, the isolation of MRSA from dairy cows with mastitis [19-21], raw milk and dairy products has been reported worldwide [22, 23], as well as in goats with mastitis $[24,25]$.

The erm $A$ and $\operatorname{erm} B$ genes were found in our study, these genes are linked to resistance to macrolides, lincosamide, and streptogramin once they belong to erythromycin ribosome methylase family of genes (ermA, ermB, and $e r m C$ ). These genes are widely distributed in isolates of Staphylococcus spp. from humans and animals and are located mainly in plasmids [26]. The presence of these genes is concerning due to the possibility of the transfer of these genes to other bacteria, or even the contamination to other animals, including humans with multiresistant bacteria.

The ant(4')-Ia gene codes for aminoglycoside modifying enzymes (AME), conferring resistance to aminoglycosides. It was found in isolates before and after treatment, but in isolates from animals 5 and 7, it appeared only after treatment.

The major facilitator superfamily (MFS) is one of the oldest and most diverse efflux system family in S. aureus, with more than 1000 members. Since its discovery, MFS transporters have become the target of studies because of the ability to confer resistance to multiple drugs [27]. The presence of MFS is clinically relevant, mainly in Gram-positive bacteria, where the most important genes for $S$. aureus norA, norB, norC and $\operatorname{lm} r S$ are located in genome [28]. The nor $A$ and nor $C$ genes confer resistance to fluorquinolones, whereas the $\operatorname{lm} r S$ gene confers resistance to linezolid, phenicol (chloramphenicol, florfenicol), trimethoprim, erythromycin, kanamycin and fusidic acid [28]. The norA, norC and $\operatorname{lmrS}$ genes were similarly detected in $S$. aureus isolated from mastitis before and after treatment, and may be an important factor related to treatment failures and the persistence of caprine mastitis. In this study, the treatment was performed with 


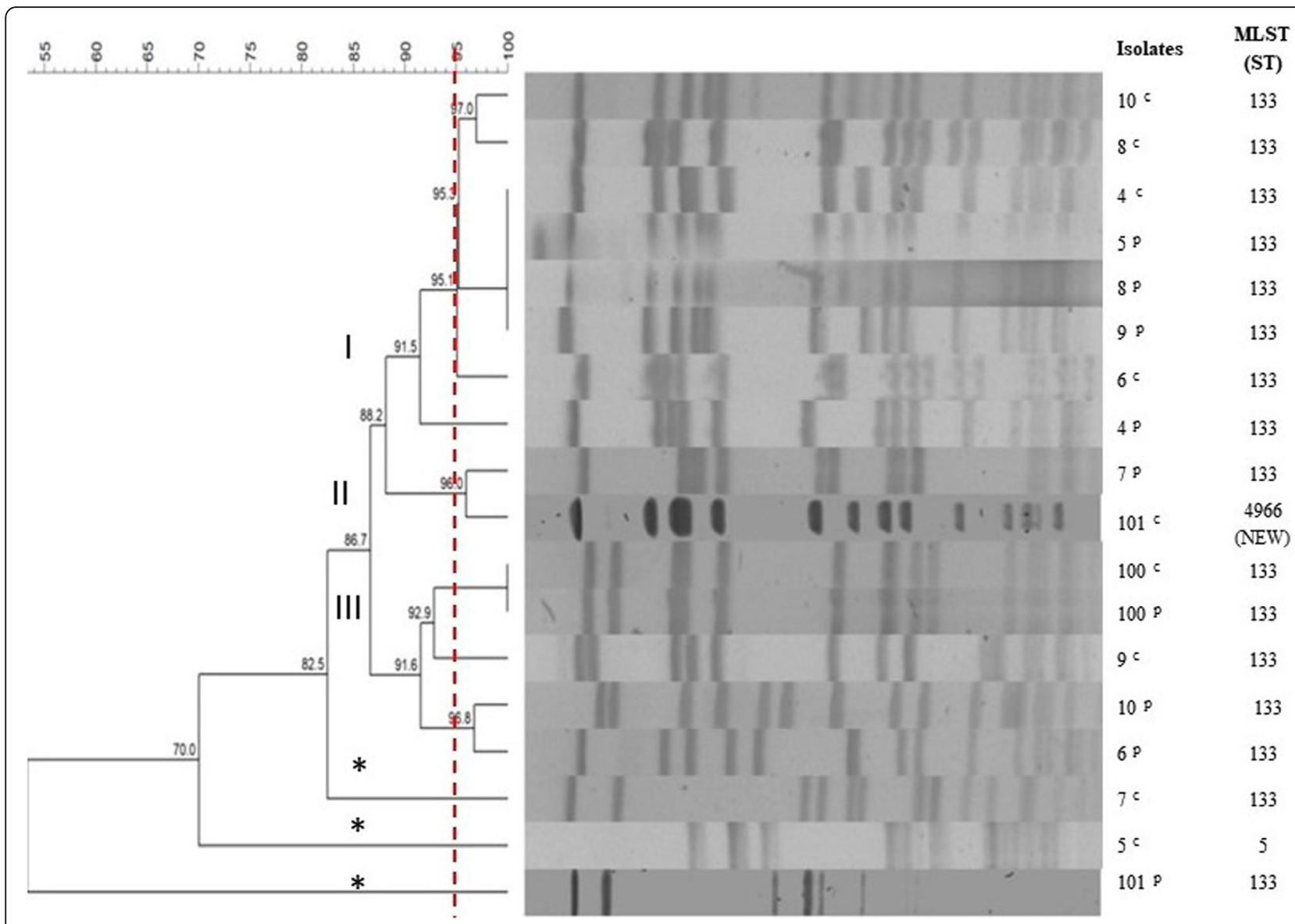

Fig. 1 Dendrogram of Pulsed Field Gel Electrophoresis of 18 Staphylococcus aureus isolates and your Sequence Types. Dendogram generated by the UPGMA/Dice (Bionumerics, Applied Maths). S. aureus isolates from the animals 4, 8 and 100, before and after treatment, presented identical pulse types (95\% similarity and 5\% tolerance and optimization). Sixteen isolates were within the same ST 133, the exceptions were S. aureus 5 and 101 from before treatment, which presented in ST 5 and a new ST 4966, respectively. c: isolates of goats with mastitis before treatment; p: isolates of goats with mastitis after treatment. Red dotted line: clusters (I-III); ${ }^{*}$ Isolated not clustered in clusters

enrofloxacin, antimicrobial for which the etiological agent was sensitive, and that has good distribution in the udder. On the other hand, enrofloxacin was known to be widely used on the property studied for the treatment of pneumonia in young goats.

The $m g r A$ gene acts as a global regulator, regulating some virulence factors such as capsule synthesis and the gene expression of multidrug efflux systems [28]. This gene acts as a negative regulator for the tet38, norB and nor $C$ genes contributing to quinolone resistance [29]. In this study, the regulatory gene $m g r A$ was not detected, suggesting that the efflux systems tet 38 and nor $C$ were active. The Tet 38 efflux system is encoded by chromosomes and confers resistance to tetracycline. In addition, the presence of this system is related to increased $S$. aureus invasion in epithelial cells, indicating that it may play new roles, in addition to resistance to antimicrobial drugs [30].

Of the 16 virulence genes tested, nine were detected (Table 2). Alpha hemolysis ( $h l a, h l b$ and $h l y$ ) permeabilizes cell membranes, destroys macrophages and lymphocytes and alters platelet morphology. ETA and ETB exfoliative toxins hydrolyze desmoglein 1 , a cadherin responsible for the integrity of the adhesive structures, resulting in skin exfoliation, and lead to the destruction of the epidermal barrier facilitating the efficient progression of infection [31].

Mørk and colleagues [32] observed the presence of $S$. aureus toxin genes obtained from healthy goats (71\%) and goats with mastitis (86\%), showing that the presence of enterotoxin-encoding genes is common in S. aureus. On the other hand, the SEC toxin affects the bovine immune response, resulting in immunosuppression, which promotes the persistence of $S$. aureus in the bovine mammary gland and contributions to chronic intramammary infection [33]. The sec gene was found in this study in three isolates before and after treatment, suggesting that this may play an important role in the virulence and persistence of this pathogen in the mammary gland of goats.

S. aureus $4^{\mathrm{C}} / 4^{\mathrm{p}}, 8^{\mathrm{c}} / 8^{\mathrm{p}}$, and $100^{\mathrm{c}} / 100^{\mathrm{p}}$ obtained from the respective animals 4,8 , and 100 , before and after 
enrofloxacin treatment, were present in pulse types, I, I, and III, respectively, and were within the same ST 133 (Fig. 1). which was previously associated with the persistence of subclinical bovine mastitis in Brazilian herds [34]. Differences in pulsotypes can alter the form of manifestation of the disease, since a given pulsotype can confer greater or lesser severity of symptoms and also be more or less associated with persistence [35]. In our study, the three pulsotypes found may be associated with persistence, but for some animals, the pulsotypes of isolates obtained from the same animal before and after treatment were different. In addition, the same resistance genes and multidrug efflux systems were found, as well as small point variations in MIC values among $S$. aureus isolated from the same animal before and after treatment (Tables 1 and 2). Regarding the presence of virulence genes, it was verified that $S$. aureus $8^{\mathrm{c}}$ and $8^{\mathrm{p}}$ have the same genes and in S. aureus 8 and 100 there was only one gene addition in $S$. aureus isolated after treatment (Table 2); thus, indicating that they may be the same isolate, which could not be eliminated in treatment and consequently resulted in persistent mastitis.

Previous studies in other geographic distributions of isolates have associated ST or Clonal Complex (CC) 133 with small ruminants [36-39]. S. aureus isolated from animals is commonly designated for host-specific ST, such as ST 133 from sheep, goats and cattle distributed in different countries [40-43]. We characterized 18 isolates of $S$. aureus, $16 \mathrm{~S}$. aureus as ST 133, one as ST 5 and one new, ST 4966, not previously described. CC 5 or ST 5 is a common clonal complex of S. aureus [44] isolated from bovine mastitis [45], including in Brazil [46], buffalo milk [47], humans and milk and dairy products samples [23, 48].

Aires-de-Souza [49] proposed that CC 133 isolates may have evolved and adapted to small ruminants, originating from humans due to adaptive diversification of the genome resulting from allelic variation, a loss of genes or the horizontal acquisition of mobile genetic elements. In the case of isolate $5^{\mathrm{c}}$ there was a modification in the allele corresponding to the yqil gene related to the metabolism of Acetylcoenzyme A acetyltransferase (Fig. 1). Isolate 101 was modified from all alleles, so it was not possible to classify it, thus resulting in a new ST. Although the other isolates (six before and six after treatment) had different pulsetypes, their resistance and virulence profiles were generally not significantly altered.

MLST provides an excellent tool for investigating the population structure of $S$. aureus globally [50]. Indeed, MLST provide data that can be compared on a global scale and allow typing of important $S$. aureus clones such as ST 5 and ST 133 involved in human and animal infections, that are non-typable by the standard PFGE method (using smaI) due to DNA methylation [51, 52].
Besides, some authors claim that the discriminatory ability of MLST is low when compared with other techniques such as PFGE [53].

The use of antimicrobials, even for therapeutic purposes, may induce the emergence of mutations, which may be related to the persistence phenomenon, by altering some of the profiles of etiological agents. Bacterial persistence is a phenomenon that involves the emergence of subpopulations of clonal groups that enter a dormant state and return to multiplication after drug withdrawal [54]. This may have occurred in the present study, where differences in resistance, virulence and clonal profiles were observed in S. aureus isolated from the same animals before and after treatment, even after a short treatment period (7 days). Cirz et al. [55] verified that, in the presence of ciprofloxacin, a fluoroquinolone, after $120 \mathrm{~min}$ of exposure, a rapid diversification of the $S$. aureus population occurs, inducing the mobilization of the prophage, as well as significant alterations to the metabolism, in addition to inducing the SOS response, leading to adaptive mutagenesis. Schelli et al. [56] found metabolic changes in response to stress in $S$. aureus isolates incubated with quinolones for a short time (after $6 \mathrm{~h}$ ).

Of the seven major genes of $S$. aureus multidrug efflux systems, five were detected in the present study in S. aureus isolates before and after treatment. Thus, the hypothesis of the persistence of isolates, which are associated with a replication arrest, biofilm production, activation of efflux pumps and stimulation of mutation events and horizontal gene transfer (HGT) [5], is reinforced.

Whereas microbial persistence describes a phenomenon in which microorganisms are considered susceptible to drugs when tested outside the host but are able to survive within the body despite the use of the appropriate antimicrobial [57], once again the persistence theory of microorganism resulting in disease persistence is emphasized.

\section{Conclusion}

This study demonstrated that $S$. aureus with certain clonal characteristics, resistance profiles and virulence possess abilities that may contribute to its persistence in mastitis, leading to severe infections and subsequent chronicity. In addition, it can be concluded that even using conventional mastitis treatment, with isolation and selection of antibiotic-sensitive in antibiogram, respecting the appropriate doses and application intervals, occasionally some profiles of the etiologic agent may be changed, contributing to the development of persistent mastitis.

\section{Methods}

This project was approved by the Committee of Ethics in the Use of Animals of the Universidade Federal de Viçosa, CEUA / UFV, with study number 42/2014. 


\section{Animals and Staphylococcus aureus isolates}

Nine animals, four Saanen and five Alpine breed (specialized breeds for milk production), aged 2-4years, with a body weight of approximately $50 \mathrm{~kg}$, identified by numbers 4, 5, 6, 7, 8, 9, 10, 100, and 101 were selected. These goats, belonging to the goat farming sector, Animal Science Department, of the Universidade Federal de Viçosa. This sector is located in Viçosa, Minas Gerais, $20^{\circ} 46^{\prime} 22.8^{\prime \prime} \mathrm{S} 42^{\circ} 51^{\prime} 10.8^{\prime \prime} \mathrm{W}$, with a Cwa climate according to Köppen climate classification. The animals are kept under intensive farming in a free stall regime, with a high-level mechanical milking system and automatic cleaning of milk pipes.

The animals selected were examined and diagnosed with clinical mastitis caused by $S$. aureus. After antibiogram results, these animals were treated with enrofloxacin (Kinetomax ${ }^{\oplus}$ - Bayer), with a dose of $5 \mathrm{mg} / \mathrm{kg}$ every $24 \mathrm{~h}$, administered intramuscularly for seven consecutive days. Twenty-one days after the completion of treatment, these animals continued to have clinical mastitis. New milk samples were collected and $S$. aureus was isolated again. Thus, 18 isolates of $S$. aureus were obtained (nine before treatment and nine after treatment). All the isolates were identified by phenotypic (morphostaining and biochemical) and genotypic (femA gene detection by PCR and sequencing) methods [58], and stored at $-80{ }^{\circ} \mathrm{C}$ in microtubes containing Heart Brain Infusion (BHI) broth with $20 \%$ glycerol.

After the experiment, the animals remained in their place of origin and returned to receive the treatment recommended by the technicians responsible for the sanitary management of the place.

S. aureus isolates were identified according to the animal number to which they were isolated and the letters $\mathrm{C}$ and $\mathrm{P}$ subscribed to the numbers means before and after treatment with enrofloxacin, respectively.

\section{Resistance profile \\ Minimum inhibitory concentration (MIC)}

The minimum inhibitory concentrations (MICs) were assessed using the E-test $\mathrm{t}^{\oplus}$ method (bioMerieux). The bacterial inoculum was prepared in Müeller-Hilton $(\mathrm{MH})$ broth and the turbidity was adjusted to McFarland scale $0.5\left(\sim 1.5 \times 10^{8} \mathrm{CFU} / \mathrm{mL}\right)$. The inoculum was spread on a plate containing $\mathrm{MH}$ agar, and the E-test strips were dispensed on the surface of the agar. The plates were then incubated at $37^{\circ} \mathrm{C}$ for $24 \mathrm{~h}$. After the incubation period, the plates were read and interpreted following the manufacturer's guidelines and published cut-off points [8, 9]. $S$. aureus ATCC $^{\oplus} 29213$ was used as control. Were tested penicillin, oxacillin, ampicillin, gentamicin, tetracycline, ciprofloxacin, vancomycin and enrofloxacin, antimicrobial agents of importance in the treatment of mastitis. The mean of three replicates was used.

\section{Virulence and resistance genes detection}

DNA extraction was performed using the Wizard ${ }^{\circledR}$ Genomic DNA Purification Kit (Promega $^{\circledR}$ ), following the protocol described for Gram-positive bacteria, modified by the addition of $100 \mu \mathrm{L}$ lysostaphin $(100 \mu \mathrm{g} / \mathrm{mL}$, Sigma ${ }^{\circ}$ and incubation at $37^{\circ} \mathrm{C}$, in a water bath for 45 min at the lysis stage.

PCR was used for detection of resistance, multidrug efflux system and virulence genes (Table 3). The PCRs was performed using $12.5 \mu \mathrm{L}$ of Green Master Mix 2X (Promega Corp.), $10 \mu \mathrm{M}$ of each primer (forward and reverse $), 2 \mu \mathrm{L}(\sim 100 \mathrm{ng} / \mu \mathrm{L})$ of DNA and nuclease-free water for the final volume of $25 \mu \mathrm{L}$ for reaction. The virulence genes $s e g+s e i$ and $s e h+s e j$ were detected using multiplex PCR [65].

The reference strains of $S$. aureus FRI 100 (sea); ATCC 14458 (seb); ATCC 19095 (sec, sec, seh and sei), FRI 472 (sed) and FRI 326 (see) were used as positive controls and were provided by Fundação Osvaldo Cruz (FiocruzRJ, Brazil).

\section{Clonal profile \\ Pulsed field gel electrophoresis (PFGE)}

Macro-restriction analyses of $S$. aureus DNA were performed following the protocol described by Spanamberg et al. [66], with some modifications. For the preparation of the plugs of the 18 isolates of S. aureus (nine before and nine after treatment), the isolates were inoculated in tryptone soy broth (TSB) and incubated at $37^{\circ} \mathrm{C}$ for 16 h, until obtaining an optical density (OD) of 1 ( $=590$ $\mathrm{nm})$. After an adjustment for OD, $150 \mu \mathrm{L}$ of the bacterial suspension was transferred to micro tubes and centrifuged at $16,000 \times g$ for $5 \mathrm{~min}$. The supernatant was discarded and the pellet was resuspended in $150 \mu \mathrm{L}$ Cell Suspension Buffer $+7 \mu \mathrm{L}$ lysostaphin $(1 \mathrm{mg} / \mathrm{mL})+7 \mu \mathrm{L}$ lysozyme $(10 \mathrm{mg} / \mathrm{mL})+150 \mu \mathrm{L}$ low melting agarose $1 \%$ and maintained at $50{ }^{\circ} \mathrm{C}$. For enzymatic digestion, about $1 / 5$ of the original plug was sectioned and added to properly identified $0.5 \mathrm{~mL}$ micro tubes. The plugs were subjected to an initial stabilization in $200 \mu \mathrm{L}$ of $1 \mathrm{X}$ enzyme buffer (TE) for $10 \mathrm{~min}$. After the removal of the buffer, $150 \mu \mathrm{L}$ of $1 \mathrm{X}$ TE was added again, accompanied by $20 \mathrm{U}$ restriction enzyme SmaI (Promega Corporation, Madison, USA), followed by incubation at $25^{\circ} \mathrm{C}$ for $4 \mathrm{~h}$.

The DNA present in the plugs was separated using a CHEF-DRIII apparatus (Bio-RadLaboratories, Hercules, CA, USA), according to the following run protocol: 40$100 \mathrm{~s}$ for $2 \mathrm{~h}$, followed by $2-35 \mathrm{~s}$ for $20 \mathrm{~h}$ at an angle of $120^{\circ}, 6 \mathrm{~V} / \mathrm{cm}$, in $0.5 \mathrm{X}$ TBE buffer maintained at $14^{\circ} \mathrm{C}$. Pulse Marker $^{\mathrm{Tm}}$ 50-1.000 kb (Sigma - Aldrich Co.) was used as a marker. The obtained gels were developed in an immersion bath with UniSafeDye ${ }^{\curvearrowleft}$ intercalating dye (Uniscience, Brazil), visualized in a transilluminator under ultraviolet light and photographed for further analysis. The obtained 
bands were analysed using BioNumerics v.6.6.4 software (AppliedMaths, Kortrijk, Belgium). For the analysis and interpretation of the results, a dendrogram was constructed using the unweighted pair group method with arithmetic mean (UPGMA) method, with a similarity coefficient of $95 \%$, and a tolerance and optimization of 5\% each [67].

\section{Multi locus sequence typing (MLST)}

Seven housekeeping genes were used: $\operatorname{arcC}$ (Carbamate kinase), aroE (shikimate dehydrogenase), $g l p F$ (glycerol kinase), gmk (guanylate kinase), pta (phosphate acetyltransferase), tpi (Triose phosphate isomerase) and yqiL (Acetyl coenzyme A) acetyl transferase) [68].

The MLST analysis was performed through PCR reactions, with each reaction containing $25 \mu \mathrm{L}$ of Green Master Mix 2X GoTaq (Promega Corp.), 10 pmol of each primer and $2 \mu \mathrm{L}(100 \mathrm{ng} / \mu \mathrm{L})$ DNA, completing the volume with free nuclease water to obtain a final volume of $50 \mu \mathrm{L}$. PCR was performed for an initial denaturation of 5 min at $95^{\circ} \mathrm{C}$, followed by 30 cycles of $55^{\circ} \mathrm{C}$ for $1 \mathrm{~min}$, extension at $72^{\circ} \mathrm{C}$ for $1 \mathrm{~min}$, and denaturation at $95^{\circ} \mathrm{C}$ for 1 min, followed by one step of final extension from $72{ }^{\circ} \mathrm{C}$ for $5 \mathrm{~min}$. We followed the protocol described by Enright et al. [68].

The amplified products were sent for sequencing at Macrogen Incorporation (Seoul, South Korea). The sequencing chromatograms were analysed and trimmed, selecting only the sequenced nucleotides with Phred scores greater $>20$ (accuracy $>99$ ). Then, contigs of the nucleotide sequences were assembled using Geneious Prime version 2019.0. Subsequently, the sequences were aligned using Multiple Sequence Alignment - CLUSTALW with the software MEGA 7.0.21. Allele profiles, sequence types (STs) and clonal complexes were assigned using the MLST database (https://pubmlst.org/saureus/). Alleles and STs that had not been previously described were submitted to the database and were assigned as a new allele numbers and STs.

\section{Statistical analyses}

The presence/absence ratio of the virulence genes, resistance and multidrug efflux system (explanatory variables) with mastitis before and after treatment (response variable) were analysed by descriptive statistics and Multinomial logistic regression. Initially, a univariate logistic regression analysis was performed; the genes that had a significant effect $(p<0.05)$ were analysed by multivariate logistic regression, and only the genes with a significant effect $(\mathrm{p}<0.05)$ were retained in the final model. The explanatory variables that did not present convergence problems in the logistic regression were evaluated by the Fisher-Freeman-Halton test. For the MIC data, descriptive statistics were used, based on the mean of three replicates. All analyses were performed using SAS version 9.3 (SAS Institute Inc., Cary, $\mathrm{NC})$.

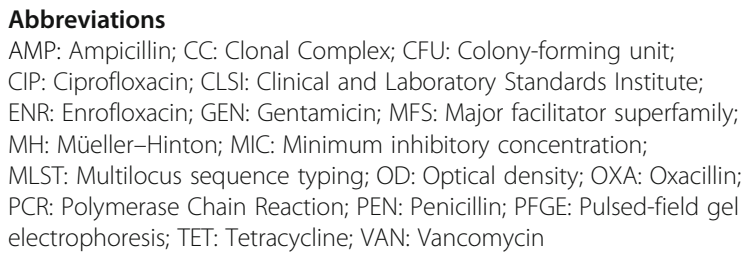

\section{Acknowledgements}

The authors would like to thank professor Ricardo Seiti Yamatogi from Universidade Federal de Viçosa for his collaboration in interpreting the results of PFGE.

\section{Authors' contributions}

$M C L$ performed, analyzed and interpreted all data and was a contributor in writing the manuscript. MB interpreted all data and was a major contributor in writing the manuscript. TMS performed and analyzed the PFGE data. RCP analyzed and interpreted MLST data. LKC and SHSG performed and analyzed PCRs. SLC and MMC analyzed and interpreted all data. MASM was the adviser, contributing in analyze and interpretation besides of defining the goals of the study. All authors have read and approved the manuscript.

\section{Funding}

Financial support was received from CNPq (Conselho Nacional de Desenvolvimento Científico e Tecnológico, Brasilia, Brazil) in the form of research funding (inputs and equipment) and scholarships, FAPEMIG (Fundação de Amparo à Pesquisa de Minas Gerais, Belo Horizonte, Brazil)) in the form of research funding (inputs and equipment) and scholarships, and CAPES (Coordenação de Aperfeiçoamento de Pessoal de Nível Superior, Brasilia, Brazil, Finance Code 001) in the form of scholarships. Maria Aparecida Scatamburlo Moreira and Mateus Matiuzzi da Costa are supported by CNPq.

\section{Availability of data and materials}

The datasets used and/or analysed during the current study are available from the corresponding author on reasonable request.

\section{Ethics approval and consent to participate}

This study was approved by the Committee of Ethics in the Use of Animals of the Universidade Federal de Viçosa, CEUAVUFV, with study number 42/2014.

\section{Consent for publication}

Not applicable.

\section{Competing interests}

The authors declare that they have no competing interests.

\section{Author details}

${ }^{1}$ Laboratory of Bacterial Diseases (LDBAC), Veterinary Department, Universidade Federal de Vicosa (UFV), PH Rolfs Avenue, s/n, University Campus, Viçosa, Minas Gerais 36570-900, Brazil. " Laboratory of Microbiology and animal immunology, Animal Science Department, Universidade Federal do Vale do São Francisco (UNIVASF), José de Sá Maniçoba Street, Center, Petrolina, Pernambuco 56306-410, Brazil.

Received: 29 January 2020 Accepted: 19 April 2020

Published online: 24 May 2020

\section{References}

1. Bergonier D, de Crémoux R, Rupp R, Lagriffoul G, Berthelot X. Mastitis of dairy small ruminants. Vet Res. 2003;34:689-716.

2. Rainard P, Gitton C, Chaumeil T, Fassier T, Huau C, Riou M, et al. Host factors determine the evolution of infection with Staphylococcus aureus to gangrenous mastitis in goats. Vet Res. 2018:1-17. https://doi.org/10.1186/ s13567-018-0564-4.

3. Elmas M, Tras B, Kaya S, Bas AL, Yazar E, Yarsan E. Pharmacokinetics of enrofloxacin after intravenous and intramuscular administration in angora goats. Can J Vet Res. 2001;65:64. 
4. Attili AR, Preziuso S, Ngwa VN, Cantalamessa A, Moriconi M, Cuteri V. Clinical evaluation of the use of enrofloxacin against Staphylococcus aureus clinical mastitis in sheep. Small Rumin Res. 2016;136:72-7. https://doi.org/10.1016/j. smallrumres.2016.01.004.

5. Brauner A, Fridman O, Gefen O, Balaban NQ. Distinguishing between resistance, tolerance and persistence to antibiotic treatment. Nat Rev Microbiol. 2016;14:320-30.

6. Martins KB, Faccioli-martins PY, Flávio D, Riboli M, Pereira VC, Fernandes S, et al. Clonal profile, virulence and resistance of Staphylococcus aureus isolated from sheep milk. Braz J Microbiol. 2015;543:535-43.

7. Spanu V, Spanu C, Virdis S, Cossu F, Scarano C, Pietro E, et al. Virulence factors and genetic variability of Staphylococcus aureus strains isolated from raw sheep's milk cheese. Int J Food Microbiol. 2012;153:53-7. https://doi. org/10.1016/j.ijfoodmicro.2011.10.015.

8. Clinical and Laboratory Standards Institute (CLSI). Performance Standards for Antimicrobial Disk Susceptibility Tests; Approved Standard-Eleventh Edition. CLSI document M02-A11 ISBN 1-56238-782-0. 950 West Valley Road, Suite 2500, Wayne, Pennsylvania 19087: Clinical and Laboratory Standards Institute; 2012

9. MacGowan AP, Wise R. Establishing MIC breakpoints and the interpretation of in vitro susceptibility tests. J Antimicrob Chemother. 2001;48(suppl_1):1728. https://doi.org/10.1093/jac/48.suppl_1.17.

10. Moroni P, Pisoni G, Vimercati C, Rinaldi M, Castiglioni B, Cremonesi P, et al. Characterization of Staphylococcus aureus isolated from chronically infected dairy goats. J Dairy Sci. 2010;88:3500-9.

11. Akkou M, Bentayeb L, Ferdji K, Medrouh B, Bachtarzi M-A, Ziane H, et al. Phenotypic characterization of staphylococci causing mastitis in goats and microarray-based genotyping of Staphylococcus aureus isolates. Small Rumin Res. 2018;169:29-33.

12. Holmes A, Ganner M, McGuane S, Pitt TL, Cookson BD, Kearns AM Staphylococcus aureus isolates carrying Panton-valentine Leucocidin genes in England and Wales: frequency, characterization, and association with clinical disease. J Clin Microbiol. 2005;43:2384-90.

13. Bien J, Sokolova O, Bozko P. Characterization of virulence factors of Staphylococcus aureus: novel function of known virulence factors that are implicated in activation of airway epithelial Proinflammatory response. J Pathog. 2011;2011:1-13.

14. Jayaraman R. Bacterial persistence: some new insights into an old phenomenon. J Biosci. 2008;33:795-805.

15. Schmitz FJ, Krey A, Sadurski R, Verhoef J, Milatovic D, Fluit AC. Resistance to tetracycline and distribution of tetracycline resistance genes in European Staphylococcus aureus isolates. J Antimicrob Chemother. 2001;47:239-40.

16. Roberts MC. Update on acquired tetracycline resistance genes. FEMS Microbiol Lett. 2005;245:195-203.

17. Kumar S, Mukherjee MM, Varela MF. Modulation of bacterial multidrug resistance efflux pumps of the major facilitator superfamily. Int J Bacteriol. 2013;2013:204141. https://doi.org/10.1155/2013/204141.

18. Oliveira DC, Tomasz A, de Lencastre $H$. Secrets of success of a human pathogen: molecular evolution of pandemic clones of meticillin-resistant Staphylococcus aureus. Lancet Infect Dis. 2002;2:180-9.

19. Wang W, Lin $X$, Jiang $T$, Peng $Z, X u$ J, Yi L, et al. Prevalence and characterization of Staphylococcus aureus cultured from raw Milk taken from dairy cows with mastitis in Beijing, China. Front Microbiol. 2018:9:1123.

20. Hata E. Bovine mastitis outbreak in Japan caused by methicillin-resistant Staphylococcus aureus New York/Japan clone. J Vet Diagn Investig. 2016;28: 291-8.

21. Rola J, Czubkowska A, Korpysa-Dzirba W, Osek J. Occurrence of Staphylococcus aureus on Farms with Small Scale Production of Raw Milk Cheeses in Poland. Toxins (Basel). 2016;8:62.

22. Tarekgne EK, Skeie S, Rudi K, Porcellato D, Narvhus JA, Skjerdal T, et al. Enterotoxin gene profile and molecular characterization of Staphylococcus aureus isolates from bovine bulk milk and milk products of Tigray regio, Northern Ethiopian. J Food Prot. 2016;79:1387-95.

23. Basanisi MG, La Bella G, Nobili G, Franconieri I, La Salandra G. Genotyping of methicillin-resistant Staphylococcus aureus (MRSA) isolated from milk and dairy products in South Italy. Food Microbiol. 2017:62:141-6.

24. Altaf M, ljaz M, Iqbal MK, Rehman A, Avais M, Ghaffar A, et al. Molecular characterization of methicillin resistant Staphylococcus aureus (MRSA) and associated risk factors with Ocurrence of goat mastitis. Pak Vet J. 2019;8318.

25. El-deeb W, Fayez M, Elmoslemany A, Kandeel M, Zidan K. Methicillin resistant Staphylococcus aureus among goat farms in Eastern province, Saudi
Arabia: Prevalence and risk factors. Prev Vet Med. 2018;156:84-90. https:// doi.org/10.1016/j.prevetmed.2018.05.005.

26. Hauschild T, Vuković D, Dakić I, Ježek P, Djukić S, Dimitrijević V, et al. Aminoglycoside resistance in members of the Staphylococcus sciuri group. Microb Drug Resist. 2007;13:77-84. https://doi.org/10.1089/mdr.2007.713.

27. Costa SS, Viveiros M, Amaral L, Couto I. Multidrug efflux pumps in Staphylococcus aureus: an update. Open Microbiol J. 2013;7:59-71.

28. Luong TT, Newell SW, Lee CY. mgr, a Novel Global Regulator in Staphylococcus aureus. J Bacteriol. 2003;185:3703, LP-710. https://doi.org/10. 1128/JB.185.13.3703-3710.2003.

29. Truong-Bolduc QC, Bolduc GR, Medeiros H, Vyas JM, Wang Y, Hooper DC. Role of the Tet38 efflux pump in Staphylococcus aureus internalization and survival in epithelial cells. Infect Immun. 2015;83:4362-72.

30. Truong-Bolduc QC, Strahilevitz J, Hooper DC. NorC, a new efflux pump regulated by MgrA of Staphylococcus aureus. Antimicrob Agents Chemother. 2006:50:1104-7.

31. Crémieux A-C, Dumitrescu O, Lina G, Vallee C, Côté J-F, Muffat-Joly M, et al. Panton-valentine Leukocidin enhances the severity of communityassociated methicillin-resistant Staphylococcus aureus rabbit osteomyelitis. PLoS One. 2009;4:e7204. https://doi.org/10.1371/journal.pone.0007204.

32. Mork T, Kvitle B, Mathisen T, Jorgensen HJ. Bacteriological and molecular investigations of Staphylococcus aureus in dairy goats. Vet Microbiol. 2010; 141:134-41.

33. Ferens WA, Davis WC, Hamilton MJ, Park YH, Deobald CF, Fox L, et al. Activation of bovine lymphocyte subpopulations by staphylococcal enterotoxin C. Infect Immun. 1998;66:573-80. http://europepmc.org/articles/ PMC107943.

34. Rossi BF, Bonsaglia ECR, Castilho IG, Dantas STA, Salina A, Langoni H, et al. Genotyping of long term persistent Staphylococcus aureus in bovine subclinical mastitis. Microb Pthogenes. 2019;132:45-50. https://doi.org/10. 1016/j.micpath.2019.04.031.

35. Haveri M, Taponen S, Vuopio-Varkila J, Salmenlinna S, Pyörälä S. Bacterial genotype affects the manifestation and persistence of bovine Staphylococcus aureus Intramammary infection. J Clin Microbiol. 2005;43: 959-61.

36. Concepción Porrero M, Hasman H, Vela Al, Fernández-Garayzábal JJ, Domínguez L, Aarestrup FM. Clonal diversity of Staphylococcus aureus originating from the small ruminants goats and sheep. Vet Microbiol. 2012; 156:157-61. https://doi.org/10.1016/j.vetmic.2011.10.015.

37. de Almeida LM, de MZPRB a, de Mendonça CL, Mamizuka EM. Novel sequence types (STs) of Staphylococcus aureus isolates causing clinical and subclinical mastitis in flocks of sheep in the northeast of Brazil. J Dairy Res. 2011;78:373-8. https://doi.org/10.1017/S0022029911000379.

38. Eriksson J, Espinosa-Gongora C, Stamphøj I, Larsen AR, Guardabassi L. Carriage frequency, diversity and methicillin resistance of Staphylococcus aureus in Danish small ruminants. Vet Microbiol. 2013;163:110-5 https://doi. org/10.1016/j.vetmic.2012.12.006

39. Guinane CM, Ben Zakour NL, Tormo-Mas MA, Weinert LA, Lowder BV, Cartwright RA, et al. Evolutionary genomics of Staphylococcus aureus reveals insights into the origin and molecular basis of ruminant host adaptation. Genome Biol Evol. 2010;2:454-66. https://doi.org/10.1093/gbe/evq031.

40. Smyth DS, Feil EJ, Meaney WJ, Hartigan PJ, Tollersrud T, Fitzgerald JR, et al. Molecular genetic typing reveals further insights into the diversity of animal-associated Staphylococcus aureus. J Med Microbiol. 2009;58:1343-53.

41. Smith EM, Needs PF, Manley G, Green LE. Global distribution and diversity of ovine-associated Staphylococcus aureus. Infect Genet Evol. 2014;22:20815. https://doi.org/10.1016/j.meegid.2013.09.008.

42. Zhou Z, Zhang M, Li H, Yang H, Li X, Song $X$, et al. Prevalence and molecular characterization of Staphylococcus aureus isolated from goats in Chongqing. China BMC Vet Res. 2017;13:352. https://doi.org/10.1186/s12917017-1272-4.

43. Hoekstra J, Rutten VPMG, van den Hout M, Spaninks MP, Benedictus L, Koop G. Differences between Staphylococcus aureus lineages isolated from ovine and caprine mastitis but not between isolates from clinical or subclinical mastitis. J Dairy Sci. 2019;102:5430-7. https://doi.org/10.3168/jds.2018-16196.

44. Monecke S, Coombs G, Shore AC, Coleman DC, Akpaka P, Borg M, et al. A field guide to pandemic, Epidemic and Sporadic Clones of MethicillinResistant Staphylococcus aureus. PLoS One. 2011;6:e17936. https://doi.org/ 10.1371/journal.pone.0017936.

45. Li T, Lu H, Wang X, Gao Q, Dai Y, Shang J, et al. Molecular characteristics of Staphylococcus aureus causing bovine mastitis between 2014 and 2015. 
Front Cell Infect Microbiol. 2017;7:127. https://www.frontiersin.org/article/1 0.3389/fcimb.2017.00127.

46. Rabello RF, Moreira BM, Lopes RMM, Teixeira LM, Riley LW, Castro ACD. Multilocus sequence typing of Staphylococcus aureus isolates recovered from cows with mastitis in Brazilian dairy herds. J Med Microbiol. 2007;56: 1505-11.

47. El-Ashker M, Gwida M, Tomaso H, Monecke S, Ehricht R, El-Gohary F, et al. Staphylococci in cattle and buffaloes with mastitis in Dakahlia governorate. Egypt J Dairy Sci. 2015;98:7450-9. https://doi.org/10.3168/jds.2015-9432.

48. Bergonier D, Sobral D, Feßler AT, Jacquet E, Gilbert FB, Schwarz S, et al. Staphylococcus aureus from 152 cases of bovine, ovine and caprine mastitis investigated by multiple-locus variable number of tandem repeat analysis (MLVA). Vet Res. 2014;45:97. https://doi.org/10.1186/s13567-014-0097-4

49. Aires-de-Sousa M, Parente CESR, Vieira-da-Motta O, Bonna ICF, Silva DA, De Lencastre H. Characterization of Staphylococcus aureus isolates from buffalo, bovine, ovine, and caprine milk samples collected in Rio de Janeiro state, Brazil $\nabla$. Appl Environ Microbiol. 2007;73:3845-9.

50. Ji Y. Methicillin-resistant Staphylococcus aureus (MRSA) protocols. Second Edi. Totowa, NJ: Humana Press; 2014.

51. Bens CCPM, Voss A, Klaassen CHW. Presence of a novel DNA methylation enzyme in methicillin-resistant Staphylococcus aureus isolates associated with pig farming leads to Uninterpretable results in standard pulsed-field gel electrophoresis analysis. J Clin Microbiol. 2006:44:1875-6.

52. Dittmann KK, Chaul LT, Lee SHI, Corassin CH, de Oliveira CAF, De Martinis ECP, et al. Staphylococcus aureus in some Brazilian dairy industries: Changes of contamination and diversity. Front Microbiol. 2017;8:2049.

53. Cohen NR, Lobritz MA, Collins JJ. Microbial persistence and the road to drug resistance. Cell Host Microbe. 2013;13:632-42. https://doi.org/10.1016/j. chom.2013.05.009

54. Pu Y, Zhao Z, Li Y, Zou J, Ma Q, Zhao Y, et al. Enhanced efflux activity facilitates drug tolerance in dormant bacterial cells. Mol Cell. 2016;62:28494. https://doi.org/10.1016/.jmolcel.2016.03.035.

55. Cirz RT, Jones MB, Gingles NA, Minogue TD, Jarrahi B, Peterson SN, et al. Complete and SOS-Mediated Response of Staphylococcus aureus to the Antibiotic Ciprofloxacin. J Bacteriol. 2007;189:531, LP-539. https://doi.org/10. 1128/JB.01464-06

56. Schelli K, Zhong F, Zhu J. Comparative metabolomics revealing Staphylococcus aureus metabolic response to different antibiotics. Microb Biotechnol. 2017;10:1764-74. https://doi.org/10.1111/1751-7915.12839.

57. Dermott WMC. Microbial persistence. Yale J Biol Med. 1958;30:257-91.

58. Lima MC, Souza MCC, Espeschit IF, Maciel PACC, Sousa JE, Moraes GF, et al. Mastitis in dairy goats from the state of Minas Gerais, Brazil: profiles of farms, risk factors and characterization of bacteria. Pesqui Vet Bras. 2018;38: 1742-51.

59. Choi SM, Kim SH, Kim HJ, Lee DG, Choi JH, Yoo JH, et al. Multiplex PCR for the detection of genes encoding aminoglycoside modifying enzymes and methicillin resistance among Staphylococcus Species. J Korean Med Sci. 2003; 18:631-6.

60. Ruegg PL, Oliveira L, Jin W, Okwumabua O. Phenotypic antimicrobial susceptibility and occurrence of selected resistance genes in gram-positive mastitis pathogens isolated from Wisconsin dairy cows. J Dairy Sci. 2015;98: 1-14. https://doi.org/10.3168/jds.2014-9137.

61. Martineau F, Picard FJ, Lansac N, Ménard C, Roy PH, Ouellette M, et al. Correlation between the resistance genotype determined by multiplex PCR assays and the antibiotic susceptibility patterns of Staphylococcus aureus and Staphylococcus epidermidis. Antimicrob Agents Chemother. 2000;44: 231-8.

62. Floyd JL, Smith KP, Kumar SH, Floyd JT, Varela MF. LmrS is a multidrug efflux pump of the major facilitator superfamily from Staphylococcus aureus. Antimicrob Agents Chemother. 2010;54:5406-12.

63. Jarraud S, Mougel C, Thioulouse J, Lina G, Meugnier H, Forey F, et al. Relationships between Staphylococcus aureus Genetic Background, Virulence Factors, agr Groups (Alleles), and Human Disease. Infect Immun. 2002;70:631 LP-641.

64. Tristan A, Ying L, Bes M, Etienne J, Vandenesch F, Lina G. Use of Multiplex PCR To Identify Staphylococcus aureus Adhesins Involved in Human Hematogenous Infections. J Clin Microbiol. 2003;41:4465 LP-4467.

65. Bania J, Dabrowska A, Korzekwa K, Zarczynska A, Bystron J, Chrzanowska J, et al. The profiles of enterotoxin genes in Staphylococcus aureus from nasal carriers. Lett Appl Microbiol. 2006:42:315-20.
66. Spanamberg A, Wunder EAJ, Brayer Pereira DI, Argenta J, Cavallini Sanches EM, Valente $P$, et al. Diversity of yeasts from bovine mastitis in southern Brazil. Rev Iberoam Micol. 2008;25:154-6.

67. Tenover FC, Arbeit RD, Goering RV, Mickelsen PA, Murray BE, Persing DH, et al. Interpreting chromosomal DNA restriction patterns produced by pulsedfield gel electrophoresis: criteria for bacterial strain typing. J Clin Microbiol. 1995;33:2233-9.

68. Enright MC, Day NPJ, Davies CE, Peacock SJ, Spratt BG. Multilocus sequence typing for characterization of methicillin-resistant and methicillin-susceptible clones of Staphylococcus aureus. J Clin Microbiol. 2000;38:1008-15.

\section{Publisher's Note}

Springer Nature remains neutral with regard to jurisdictional claims in published maps and institutional affiliations.
Ready to submit your research? Choose BMC and benefit from:

- fast, convenient online submission

- thorough peer review by experienced researchers in your field

- rapid publication on acceptance

- support for research data, including large and complex data types

- gold Open Access which fosters wider collaboration and increased citations

- maximum visibility for your research: over $100 \mathrm{M}$ website views per year

At BMC, research is always in progress.

Learn more biomedcentral.com/submissions 